\title{
Susceptibility role of soluble HLA-G and HLA-G 14-bp insertion/deletion polymorphism in inflammatory bowel disease
}

Sarah S. Abdul-Hussein ${ }^{1}$, Ekhlass N. Ali', Nawal M. F. Alkhalidi², Neihaya H. Zaki ${ }^{1}$ and Ali H. Ad'hiah ${ }^{3^{*}}$ (D)

\begin{abstract}
Background: Inflammatory bowel disease (IBD) is a group of chronic inflammatory disorders of the gastrointestinal tract. It is fundamentally related to a dysregulated immune response in the intestinal mucosa against microbiota in genetically predisposed individuals. Among the genetic and immunological factors that are suggested to have role in etiology and pathogenesis of IBD are human leukocyte antigen (HLA)-G molecules. Therefore, soluble HLA-G (sHLA-G) serum level and genetic association with HLA-G 14-bp insertion (Ins)/deletion (Del) polymorphism was analyzed in 100 IBD patients; 50 ulcerative colitis (UC) and 50 Crohn's disease (CD), and 100 controls.

Results: $\mathrm{SHLA}-\mathrm{G}$ level was significantly elevated in IBD patients compared to controls (174.7 \pm 27.1 vs. $126.8 \pm 15.1$; corrected probability $[\mathrm{pc}]<0.001$ ). The level was also elevated in UC patients compared to CD patients but the difference was not significant (180.5 \pm 27.1 vs. $168.9 \pm 26.3 ; p=0.059)$. Receiver operating characteristic analysis confirmed the significance of sHLA-G in total IBD, UC, and CD patients (area under curve $=0.944,0.961$, and 0.927, respectively). The genetic association was analyzed under five genetic models (allele, recessive, dominant, overdominant, and codominant). At the allele level, Del allele frequency was significantly increased in total IBD patients (Odds ratio $[\mathrm{OR}]=1.93 ; 95 \%$ confidence interval $[\mathrm{Cl}]=1.27-2.94 ; \mathrm{pC}=0.018)$ and $\mathrm{CD}$ patients $(\mathrm{OR}=2.08$; $95 \% \mathrm{Cl}=1.23-3.54 ; \mathrm{pC}=0.042)$ compared to controls. Among UC patients, a similar increased frequency was observed, but the $\mathrm{pc}$ value was not significance $(\mathrm{OR}=1.79 ; 95 \% \mathrm{Cl}=1.07-3.00 ; p=0.031)$. At the genotypic level, Del/Del genotype was associated with a significantly increased IBD-risk in total patients under codominant model $(\mathrm{OR}=4.06 ; 95 \% \mathrm{Cl}=1.56-10.56 ; \mathrm{pC}=0.024)$. sHLA-G level was not influenced by the Ins/Del polymorphism.
\end{abstract}

Conclusions: This study demonstrated a significant increase in serum level of sHLA-G in UC and CD patients. Further, HLA-G 14-bp Ins/Del polymorphism may be associated with susceptibility to IBD, particularly CD.

Keywords: Inflammatory bowel disease, Ulcerative colitis, Crohn's disease, Soluble HLA-G, 14-bp Ins/Del polymorphism

\footnotetext{
* Correspondence: dr.ahadhiah@sc.uobaghdad.edu.iq;

dr.a.h.adhiah@gmail.com

${ }^{3}$ Tropical-Biological Research Unit, College of Science, University of Baghdad,

Al-Jadriya, Baghdad, Iraq

Full list of author information is available at the end of the article
}

\section{Springer Open}

(c) The Author(s). 2020 Open Access This article is licensed under a Creative Commons Attribution 4.0 International License, which permits use, sharing, adaptation, distribution and reproduction in any medium or format, as long as you give appropriate credit to the original author(s) and the source, provide a link to the Creative Commons licence, and indicate if changes were made. The images or other third party material in this article are included in the article's Creative Commons licence, unless indicated otherwise in a credit line to the material. If material is not included in the article's Creative Commons licence and your intended use is not permitted by statutory regulation or exceeds the permitted use, you will need to obtain permission directly from the copyright holder. To view a copy of this licence, visit http://creativecommons.org/licenses/by/4.0/. 


\section{Background}

Inflammatory bowel disease (IBD) is a group of chronic inflammatory disorders of the gastrointestinal tract. It is fundamentally related to a dysregulated immune response in the intestinal mucosa against microbiota in genetically predisposed individuals [1]. Two major phenotypes of IBD are clinically recognized: ulcerative colitis (UC) and Crohn's disease (CD). The inflammation in $\mathrm{UC}$ is restricted to the colon and rectum, while in $\mathrm{CD}$, it involves any part of the gastrointestinal tract in a noncontinuous fashion [2]. Their clinical presentations are similar, but diarrhea and bleeding are most likely presented in UC, whereas watery diarrhea and vague symptoms are encountered in CD [3]. Etiology of both phenotypes is incompletely understood, but complex interactions between genetic, environmental, immunological, and gut microbiomial factors are suggested to be involved. Their interactions orchestrate a cascade of inflammatory responses in the intestinal mucosa [4]. Among the genetic and immunological factors that are proposed to have a role in etiology and pathogenesis of IBD are human leukocyte antigen (HLA)-G molecules, which are encoded by the non-classical major histocompatibility (MHC) class I genes that are mapped to the short arm of chromosome 6 (6p21.3) [5-7].

HLA-G molecules are characterized by restricted tissue expression. Under non-pathological conditions, they are principally expressed on the extra-villous cytotrophoblast cells and tissues at the feto-maternal interface [8]. Functionally, HLA-G molecules create a state of tolerance to protect the fetus from the maternal immune response against the fetal semi-allograft [9]. The tolerogenic properties of HLA-G molecules are augmented through interactions with cell-surface receptors present on natural killer (NK) cells, T and B cells and antigenpresenting cells [10]. However, upregulation of HLA-G has also been demonstrated under pathological conditions, especially in diseases characterized by inflammation. Therefore, it has been suggested that these molecules enhance immune surveillance as a possible mechanism of tissue protection against inflammatory responses [11-13]. Seven isoforms of HLA-G molecules are recognized (HLA-G1-G7). The first four isoforms (G1-G4) are cellsurface bound proteins, while G5-G7 are soluble proteins (sHLA-G) [8].

The HLA-G gene is presented with low allelic polymorphism compared other classical HLA-class I molecules. Up to April 2020, 78 alleles have been recognized at the DNA level and 21 alleles at the protein level, as well as, four null alleles have also been registered [14]. In addition, HLA-G gene exhibits a further polymorphism, which is 14 base-pairs (14-bp) insertion (Ins)/deletion (Del) at the $3^{\prime}$ untranslated region (3' UTR) of exon 8 . Investigations have linked this polymorphism to post-transcriptional regulation of HLA-G molecules, and thus its effect on the stability of mRNA has been proposed $[15,16]$.

The role of HLA-G molecules in pathogenesis of IBD or their effect on susceptibility to disease has not been wellelaborated. In 2004, the expression of HLA-G in intestinal biopsies was analyzed in $\mathrm{UC}$ and $\mathrm{CD}$ patients. It was found that HLA-G was only expressed in biopsies of UC patients, whereas CD samples showed no expression [17]. In a further study, the level of sHLA-G was determined in supernatants of cultured peripheral blood mononuclear cells (PBMCs) obtained from $18 \mathrm{UC}$ and $10 \mathrm{CD}$ patients. The results showed different expression of sHLA-G between the two phenotypes of IBD, and a spontaneous secretion of sHLA-G was depicted in CD patients but not in UC or healthy subjects [18]. In a more recent immunohistochemical study, expression of HLA-G was noticed in UC and CD biopsies; however, the expression of HLA-G5 isoform was differentially correlated with levels of tumor necrosis factor- $\alpha$ (TNF- $\alpha$ ) and interleukin-10 (IL-10) [7]. With regard to HLA-G 14-bp Ins/Del polymorphism, two previous studies suggested the significance of this polymorphism in IBD risk $[19,20]$.

Due to the growing importance of HLA-G molecules in etiology and pathogenesis of IBD (UC and CD), this study analyzed serum level of sHLA-G in UC and CD of Iraqi Arab patients categorized according to gender, cigarette-smoking status, disease duration, family history, disease extension and medication. The genetic association of HLA-G 14-bp Ins/Del polymorphism with both phenotypes of IBD was also analyzed.

\section{Methods}

\section{Populations studied}

During January-June 2019, a case-control study was conducted on 100 Iraqi Arab IBD patients (50 UC and $50 \mathrm{CD})$. Ethnicity matched 100 healthy subjects were taken as controls. The patients attended the outpatient gastrointestinal clinics at Al-Kindy Teaching Hospital, Baghdad Teaching Hospital and Gastroenterology and Hepatology Teaching Hospital in Baghdad for diagnosis and treatment. The diagnosis was based on standard clinical, radiological, endoscopic, and histopathological criteria [3]. Patients with indeterminate colitis or other related autoimmune diseases were excluded. The patients were stratified according the following parameters: age, gender, current cigarette-smoking status, disease duration, family history, laboratory findings (hemoglobin; $\mathrm{Hb}$, white blood cell count; WBC and erythrocyte sedimentation rate; ESR), disease extension, symptoms, extra-intestinal manifestations, and medication (Table 1). The control sample included blood donors who were healthy and there serum profile for anti-pathogen antibodies was negative (Central Blood Bank, Baghdad). All participants gave 
Table 1 Baseline characteristics of inflammatory bowel disease (ulcerative colitis and Crohn's disease) patients and controls

\begin{tabular}{|c|c|c|c|c|}
\hline Characteristics $^{\mathrm{a}}$ & UC $(N=50)$ & $\mathrm{CD}(N=50)$ & Controls $(N=100)$ & $p$ \\
\hline Age & $31.5 \pm 10.1$ & $30.5 \pm 9.7$ & $31.2 \pm 9.8$ & 0.864 \\
\hline Gender & & & & 0.990 \\
\hline Male & $28(56.0)$ & $28(56.0)$ & $57(57.0)$ & \\
\hline Female & $22(44.0)$ & $22(44.0)$ & $43(43.0)$ & \\
\hline Cigarette-smokers & $40(80.0)$ & $35(70.0)$ & 39 (39.0\%) & $<0.001$ \\
\hline Disease duration (years) & & & & 0.314 \\
\hline$\leq 3$ & $20(40.0)$ & $25(50.0)$ & NA & \\
\hline$>3$ & $30(60.0)$ & $25(50.0)$ & NA & \\
\hline Positive family history & $7(14.0)$ & $8(16.0)$ & NA & 0.779 \\
\hline $\mathrm{Hb}(\mathrm{mg} / \mathrm{dL})$ & $11.0 \pm 3.0$ & $10.5 \pm 3.5$ & NA & 0.682 \\
\hline WBC $\left(\times 10^{9} / L\right)$ & $8.1 \pm 3.6$ & $7.7 \pm 3.1$ & NA & 0.783 \\
\hline ESR (mm/hour) & $54.3 \pm 22.5$ & $58.8 \pm 42.4$ & NA & 0.876 \\
\hline
\end{tabular}

\section{Disease extension}

\begin{tabular}{|c|c|c|c|c|}
\hline Ulcerative proctitis & $20(40.0)$ & NA & \multicolumn{2}{|l|}{ NA } \\
\hline Left-sided colitis & $15(30.0)$ & NA & NA & \\
\hline Extensive colitis & $15(30.0)$ & NA & NA & \\
\hline Ileocecal & NA & $43(86.0)$ & NA & \\
\hline Ileo-colonic & NA & $7(14.0)$ & NA & \\
\hline \multicolumn{5}{|l|}{ ymptoms } \\
\hline Abdominal/or colon pain & $33(66.0)$ & $33(66.0)$ & NA & 1.000 \\
\hline Diarrhea & $29(58.0)$ & $27(54.0)$ & NA & 0.840 \\
\hline Fever & $22(44.0)$ & $27(54.0)$ & NA & 0.424 \\
\hline \multicolumn{5}{|c|}{ xtra-intestinal manifestations } \\
\hline Aphthous ulcer & $9(18.0)$ & $15(30.0)$ & NA & 0.241 \\
\hline Arthralgia & $34(68.0)$ & $38(72.0)$ & NA & 0.504 \\
\hline Skin ulcer & $7(14.0)$ & $3(6.0)$ & NA & 0.318 \\
\hline Appendectomy & $6(12.0)$ & $7(14.0)$ & NA & 1.000 \\
\hline Bowel stricture & $4(8.0)$ & $3(6.0)$ & NA & 1.000 \\
\hline Colostomy & $5(10.0)$ & $6(12.0)$ & NA & 1.000 \\
\hline Fistula & $10(20.0)$ & $6(12.0)$ & NA & 0.414 \\
\hline Hemorrhoids & $6(12.0)$ & $3(6.0)$ & NA & 0.487 \\
\hline \multicolumn{3}{|l|}{ Medication } & & 0.556 \\
\hline Protocol A & $14(28.0)$ & $12(24.0)$ & & \\
\hline Protocol B & $12(24.0)$ & $8(16.0)$ & & \\
\hline Protocol C & $11(22.0)$ & $11(22.0)$ & & \\
\hline Protocol D & $13(26.0)$ & $19(38.0)$ & & \\
\hline \multicolumn{3}{|c|}{ dalimumab or infliximab doses } & & 0.614 \\
\hline 0 & $12(24.0)$ & $8(16.0)$ & & \\
\hline $1-10$ & $20(40.0)$ & $18(36.0)$ & & \\
\hline $11-20$ & $13(26.0)$ & $18(36.0)$ & & \\
\hline $21-30$ & $5(10.0)$ & $6(12.0)$ & & \\
\hline
\end{tabular}

${ }^{a}$ Data are either mean \pm standard deviation or absolute number followed by percentage in parentheses: UC ulcerative colitis, $C D$ Crohn's disease, Hb hemoglobin, WBC white blood cell, ESR erythrocyte sedimentation rate, protocol $A$ anti-inflammatory and immunosuppressive, protocol $B$ anti-inflammatory and antibiotics, protocol $C$ anti-inflammatory, immunosuppressive and antibiotics, protocol $D$ immunosuppressive only. $p$ LSD (least significant), Pearson's chi-squared or Fisher's exact test probability, NA not applicable. Significant $p$ is bold-marked 
written consent to participate in the study. The approval of Ethics Committees at the target hospitals was obtained to conduct the study (N264 on 13/01/2019). All participants (50 UC and $50 \mathrm{CD}$ and 100 controls) were genotyped for HLA-G 14-bp Ins/Del polymorphism, while serum level of sHLA-G was determined in 90 randomly selected participants ( $30 \mathrm{UC}, 30 \mathrm{CD}$, and 30 controls).

\section{Determination sHLA-G}

Serum level of sHLA-G was determined using human HLA-G enzyme-linked immunosorbent assay kit (catalog no.: E-EL-H1663) according to instructions of manufacturer (Elabscience, China).

\section{Genotyping of HLA-G 14-bp Ins/Del polymorphism}

Genomic DNA was isolated from EDTA blood using DNA purification kit (Geneaid, Taiwan) following instructions of manufacturer. Sequence-specific polymerase chain reaction (PCR) assay was accomplished to genotype 14-bp Ins/Del polymorphism in exon 8 of HLAG gene (3'-untranslated region) using a thermocycler (Eppendorf, Germany) followed by agarose gel electrophoresis as previously depicted [21]. Briefly, the reaction mix $(25 \mu \mathrm{L})$ consisted of $5 \mu \mathrm{L}$ DNA $(60 \mathrm{ng} / \mathrm{mL}), 12.5 \mu \mathrm{L} 1 \times$ Green Master mix (Bioneer, Korea), $1 \mu \mathrm{L}$ forward primer (5'GTGATGGGCTGTTTAAAGTGTCACC-3'; 10 pmol/ $\mu \mathrm{L}), \quad 1 \mu \mathrm{L}$ reverse primer (5'-GGAAGGAATGCAGT TCAGCATGA -3 ; $10 \mathrm{pmol} / \mu \mathrm{L}$ ) and $5 \mu \mathrm{L}$ nuclease-free water. The optimized thermocycling conditions were initial denaturation at $94{ }^{\circ} \mathrm{C} \min (5 \mathrm{~min})$, followed by $35 \mathrm{cy}$ cles of denaturation and $94{ }^{\circ} \mathrm{C}(30 \mathrm{~s})$, annealing at $60{ }^{\circ} \mathrm{C}$ (30 s), and extension at $72{ }^{\circ} \mathrm{C}(30 \mathrm{~s})$, and a final extension cycle at $72{ }^{\circ} \mathrm{C}$ for $5 \mathrm{~min}$. The amplified PCR products were electrophoresed in 3\% agarose gels. The bands were visualized with UV trans-illuminator after staining with ethidium bromide. Product sizes were $210 \mathrm{bp}$ and $224 \mathrm{bp}$ for Del and Ins alleles, respectively.

\section{Statistical analysis}

Data were statistically analyzed using the statistical package IBM SPSS Statistics 25.0 (Armonk, NY: IBM Corp.). Categorical variables were given as numbers and percentages. Continuous variables were tested for normality distribution (Kolmogorov-Smirnov and Shapiro-Wilk tests). All continuous variables were normally distributed; therefore, they were presented as mean \pm standard deviation (SD). Pearson's chi-squared and Fisher's exact tests were used to compare categorical variables. Oneway analysis of variance (ANOVA) was used to compare continuous variables followed by the post hoc test LSD (least significant difference). Receiver operating characteristic (ROC) was used to determine area under curve (AUC), sensitivity, specificity, and cut-off value. Direct gene counting method was used to estimate allele frequencies of Del/Ins 14-bp polymorphism. Assumption of Hardy-Weinberg equilibrium (HWE) was tested using Pearson's chi-squared goodness-of-fit test. Logistic regression analysis was employed to calculate odds ratio (OR) and 95\% confidence interval (CI) under five genetic models (allele, recessive, dominant, overdominant and codominant). A probability $(p)$ value $\leq 0.05$ was considered significant after applying Bonferroni correction (corrected $p$; $\mathrm{pc}$ ). G*Power software (version 3.1.9.4) was used to estimate power of sample size.

\section{Results}

\section{Power of sample size}

Power of sample size (1- $\beta$ error probability) was estimated for UC and CD. At an $\alpha$ error of probability of 0.05 and an effect size of 0.3 , the power for a sample size of 50 cases was 0.71 , which was below the marginal power of 0.8 . However, merging $\mathrm{UC}$ and $\mathrm{CD}$ cases in one group (IBD) elevated the power to 0.93 .

\section{Baseline characteristics of populations studied}

Mean age and gender distribution showed no significant variation between IBD patients (UC and $C D$ ) and control. However, most of $\mathrm{UC}$ and $\mathrm{CD}$ patients were cigarette-smokers (80.0 and $70.0 \%$, respectively), while among control, smokers accounted for $39.0 \%$. Such difference was statistically significant $(p<0.001)$. There were no significant differences between $U C$ and $C D$ patients regarding disease duration ( $\leq 3$ and $>3$ years), positive family history, laboratory findings $(\mathrm{Hb}, \mathrm{WBC}$, and ESR), symptoms (abdominal pain, diarrhea and fever), and extra-intestinal manifestations (aphthous ulcer, arthralgia, skin ulcer, appendectomy, bowel stricture, colostomy, fistula, and hemorrhoids). With regard to disease extension, UC patients were classified as ulcerative proctitis (40\%), left-sided colitis (30\%), and extensive colitis (30\%), while most of CD patients were classified under ileocecal colitis (86\%). For medication, four protocols were used: antiinflammatory and immunosuppressive, anti-inflammatory and antibiotics, anti-inflammatory, antibiotics and immunosuppressive, and immunosuppressive only. Patients who received the immunosuppressive medicines adalimumab or infliximab were divided into four groups according to the number of doses received: $0,1-10,11-20$, and 2130 doses (Table 1).

\section{Serum level of sHLA-G}

Serum level of sHLA-G was significantly elevated in IBD patients compared to controls $(174.7 \pm 27.1$ vs. $126.8 \pm$ 15.1; pc < 0.001). The level was also elevated in UC patients compared to $\mathrm{CD}$ patients but the difference was not significant $(180.5 \pm 27.1$ vs. $168.9 \pm 26.3 ; p=0.059)$ (Table 2). ROC analysis confirmed the significance of sHLA-G antigens in total IBD patients, as well as UC 
Table 2 Serum level of soluble HLA-G antigens in inflammatory bowel disease (ulcerative colitis and Crohn's disease) patients and controls

\begin{tabular}{llll}
\hline Group & sHLA-G $($ mean \pm SD); $\mathbf{n g} / \mathbf{m l}$ & $\boldsymbol{p}_{\mathbf{1}}$ & $\boldsymbol{p}_{\mathbf{2}}$ \\
\hline Controls $(N=30)$ & $126.8 \pm 15.1$ & & \\
$\operatorname{IBD}(N=60)$ & $174.7 \pm 27.1$ & $<\mathbf{0 . 0 0 1}$ & \\
UC $(N=30)$ & $180.5 \pm 27.1$ & $<\mathbf{0 . 0 0 1}$ & 0.059 \\
CD $(N=30)$ & $168.9 \pm 26.3$ & $<\mathbf{0 . 0 0 1}$ & \\
\hline
\end{tabular}

Significant $p$ is bold-marked

IBD inflammatory bowel disease, UC ulcerative colitis, CD Crohn's disease, $p_{1}$ LSD (least significant difference) probability compared to control, $p_{2}$ UC vs. CD

and CD patients (AUC $=0.944,0.961$, and 0.927, respectively) (Fig. 1).

\section{sHLA-G and characteristics of patients}

UC male patients showed a significantly elevated mean of sHLA-G antigens compared to female patients (192.0 \pm 24.1 vs. $170.5 \pm 26.2$; pc $=0.03$ ) or control males $(192.0 \pm 24.1$ vs. $173.5 \pm 25.1$; pc $=0.05)$. Cigarettesmoker UC patients also showed a significant increase in mean of sHLA-G compared to smoker CD patients $(187.9 \pm 24.2$ vs. $162.8 \pm 25.9 ; \mathrm{pc}=0.04)$. However, distributing $\mathrm{UC}$ and $\mathrm{CD}$ patients according to the other characteristics revealed no significant variations in sHLA-G levels (Table 3).

\section{Frequency of HLA-G 14-bp Ins/Del polymorphism in controls}

Genotype frequencies of HLA-G 14-bp Ins/Del polymorphism in controls of this study were in a good agreement with HWE equilibrium. The allele Del was more frequently observed than Ins allele (59 vs. 41\%). However, allele and genotype frequencies of the HLA-G 14bp Ins/Del polymorphism showed significant variation compared with other world populations (Table 4).

\section{HLA-G 14-bp Ins/Del polymorphism-disease association}

Five genetic models (allele, recessive, dominant, overdominant, and codominant) were adopted to assess the genetic association of HLA-G 14-bp Ins/Del polymorphism with IBD, UC and CD. At the allele level (Del vs. Ins), frequency of $\mathrm{Del}$ allele frequency was significantly increased in total IBD patients $(\mathrm{OR}=1.93 ; 95 \% \mathrm{CI}=1.27-2.94 ; \mathrm{pc}=$ $0.018)$ and $C D$ patients $(\mathrm{OR}=2.08 ; 95 \% \mathrm{CI}=1.23-3.54$; $\mathrm{pc}=0.042)$ compared to controls. In UC, a similar increased frequency was observed, but the significance was lost when the $p$-value was corrected $(\mathrm{OR}=1.79 ; 95 \% \mathrm{CI}=$ $1.07-3.00 ; p=0.031)$. At the genotypic level, none of the adopted genetic models revealed variation with a corrected significant $p$ value between patients and controls. The codominant model was an exception in total IBD patients. The Del/Del genotype vs. Ins/Ins maintained a significantly corrected $p$ value $(\mathrm{OR}=4.06 ; 95 \% \mathrm{CI}=1.56-$ 10.56; pc $=0.024)($ Table 5).

\section{Impact of HLA-G 14-bp Ins/Del polymorphism on sHLA-G level \\ Serum level of sHLA-G antigens was inspected in the three genotypes of HLA-G 14-bp Ins/Del polymorphism of IBD patients (UC and CD) and controls, and no sig- nificant impact of genotypes was recorded (Table 6).}

\section{Discussion}

Among the characteristics that showed significant variation in UC and CD compared to controls was cigarettesmoking. Most of the patients were smokers (80 and $70 \%$, respectively). This may underline a casual relation between IBD and cigarette-smoking; however, the literature disclosed that smoking has a dichotomous effect in $\mathrm{UC}$ and $\mathrm{CD}$ [38]. In CD, it has been established that smoking is a prominent environmental risk factor, and has a significant impact on disease development among smokers. Moreover, increased risk of relapse, steroid requirements, and hospitalization were associated with tobacco exposure. Conversely, cigarette-smoking is considered an environmental protective factor in UC, and a reduced risk of disease has been reported in active smokers. However, a reduced risk of developing UC has also been identified in patients who have never smoked. Therefore, the association between cigarette-smoking and UC is not yet fully understood [39].

The principal aim of present study was to understand the role HLA-G molecules in etiology and pathogenesis of UC and CD. Two approaches were adopted. In the first, serum level of sHLA-G was determined. In both IBD phenotypes, the level was significantly elevated in patients compared to controls. Further, ROC analysis depicted that sHLA-G occupied a significant AUC in IBD, but was higher in UC than in CD (0.961 vs. 0.927). Accordingly, it is suggested that sHLA-G molecules are risk factors with detrimental effect on the pathological course of UC and CD. There is no direct evidence to support these findings and previous studies investigating sHLA-G role in pathogenesis of UC or CD have not been well-elaborated. Consistent with this study, a significantly elevated level of sHLA-G was reported in CD patients compared to controls [20]. However, in an earlier study, the mucosal expression of HLA-G was detected in UC samples, while biopsies of CD patients did not show the expression of HLA-G molecules [17], whereas, a recent study demonstrated their gene and protein expression in biopsies of UC and CD patients [7]. In an in vitro study, the supernatant of cultured PBMCs obtained from UC and CD patients was examined for sHLA-G molecules using ELISA. This time, UC patients showed no detectable level of sHLA-G, while 

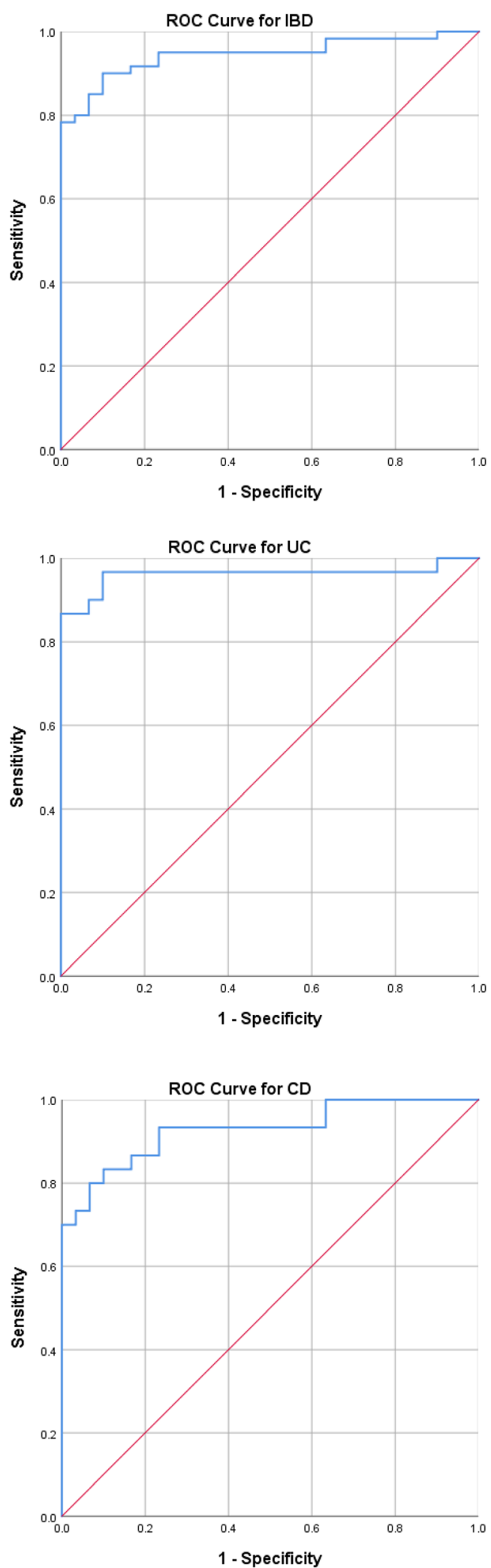

Fig. 1 Receiver operating characteristic (ROC) analysis for sHLA-G antigens showing area under curve (AUC) in IBD ( $A U C=0.944 ; 95 \% \mathrm{Cl}=0.898-0.990 ; p<$ 0.001; sensitivity = 90.0\%; specificity = 90.0\%; cut-off value $=145.2 \mathrm{ng} / \mathrm{ml}), \mathrm{UC}(\mathrm{AUC}=0.961 ; 95 \% \mathrm{Cl}=0.902-1.000 ; p<0.001$; sensitivity $=96.7 \%$; specificity $=$ 90.0\%; cut-off value $=145.2 \mathrm{ng} / \mathrm{ml})$ and CD (AUC $=0.928 ; 95 \% \mathrm{Cl}=0.860-0.993 ; p<0.001 ;$ sensitivity $=83.3 \%$; specificity $=83.3 \% ;$ cut-off value $=145.2 \mathrm{ng} / \mathrm{ml})$ 
Table 3 Serum level of soluble HLA-G antigens in ulcerative colitis and Crohn's disease distributed according to some characteristics of patients

\begin{tabular}{|c|c|c|c|}
\hline \multirow[t]{2}{*}{ Characteristic } & \multicolumn{2}{|c|}{ sHLA-G (mean \pm SD); ng/ml } & \multirow[t]{2}{*}{$p(\mathrm{pc})$} \\
\hline & UC $(N=30)$ & $\mathrm{CD}(N=30)$ & \\
\hline \multicolumn{4}{|l|}{ Gender } \\
\hline Male & $192.0 \pm 24.1$ & $173.5 \pm 25.1$ & $0.005(0.050)$ \\
\hline Female & $170.5 \pm 26.2$ & $164.9 \pm 27.5$ & 0.542 (NS) \\
\hline$p(p c)$ & $0.003(0.030)$ & 0.292 (NS) & \\
\hline \multicolumn{4}{|c|}{ Cigarette smoking status } \\
\hline Smoker & $187.9 \pm 24.2$ & $162.8 \pm 25.9$ & $0.004(0.040)$ \\
\hline Non-smoker & $165.9 \pm 27.9$ & $175.0 \pm 26.2$ & 0.419 (NS) \\
\hline$p(p c)$ & $0.033(N S)$ & $0.181(\mathrm{NS})$ & \\
\hline \multicolumn{4}{|l|}{ Disease duration (years) } \\
\hline$\leq 3$ & $175.1 \pm 32.2$ & $164.9 \pm 24.0$ & 0.362 (NS) \\
\hline \multirow[t]{2}{*}{$>3$} & $184.1 \pm 23.4$ & $172.9 \pm 28.7$ & 0.233 (NS) \\
\hline & 0.376 (NS) & 0.417 (NS) & \\
\hline \multicolumn{4}{|l|}{ Family history } \\
\hline Yes & $193.3 \pm 31.7$ & $174.7 \pm 23.4$ & 0.332 (NS) \\
\hline No & $178.6 \pm 26.5$ & $167.8 \pm 27.2$ & 0.152 (NS) \\
\hline$p(p c)$ & 0.352 (NS) & 0.647 (NS) & \\
\hline \multicolumn{4}{|l|}{ Disease extension } \\
\hline Ulcerative proctitis & $185.4 \pm 32.3$ & & \\
\hline Left-sided colitis & $170.2 \pm 19.3$ & & \\
\hline Extensive colitis & $182.6 \pm 25.0$ & & \\
\hline Ileocecal & & $171.6 \pm 25.2$ & \\
\hline Ileo-colonic & & $155.3 \pm 30.5$ & \\
\hline$p(p c)$ & 0.457 (NS) & 0.212 (NS) & \\
\hline \multicolumn{4}{|c|}{ Abdominal/or colon pain } \\
\hline Present & $184.7 \pm 29.9$ & $165.1 \pm 23.6$ & $0.030(N S)$ \\
\hline Absent & $169.1 \pm 12.5$ & $174.0 \pm 29.7$ & 0.662 (NS) \\
\hline$p(p c)$ & 0.558 (NS) & 0.841 (NS) & \\
\hline \multicolumn{4}{|l|}{ Diarrhea } \\
\hline Present & $184.6 \pm 23.1$ & $165.0 \pm 27.6$ & $0.032(N S)$ \\
\hline Absent & $172.3 \pm 33.6$ & $171.9 \pm 25.8$ & 1.000 (NS) \\
\hline$p(\mathrm{pc})$ & 0.224 (NS) & 0.485 (NS) & \\
\hline \multicolumn{4}{|l|}{ Fever } \\
\hline Present & $192.3 \pm 27.0$ & $169.4 \pm 28.7$ & 0.051 (NS) \\
\hline Absent & $171.6 \pm 24.2$ & $168.6 \pm 25.5$ & 0.725 (NS) \\
\hline$p(\mathrm{pc})$ & $0.040(N S)$ & 1.000 (NS) & \\
\hline \multicolumn{4}{|l|}{ Medication } \\
\hline Protocol A & $191.9 \pm 23.6$ & $167.6 \pm 32.7$ & 0.085 (NS) \\
\hline Protocol B & $189.7 \pm 26.3$ & $159.8 \pm 10.3$ & 0.079 (NS) \\
\hline Protocol C & $167.5 \pm 15.3$ & $181.8 \pm 19.2$ & 0.199 (NS) \\
\hline Protocol D & $170.8 \pm 32.0$ & $165.2 \pm 29.4$ & 0.741 (NS) \\
\hline$p(p c)$ & 0.119 (NS) & 0.184 (NS) & \\
\hline
\end{tabular}


Table 3 Serum level of soluble HLA-G antigens in ulcerative colitis and Crohn's disease distributed according to some characteristics of patients (Continued)

\begin{tabular}{|c|c|c|c|}
\hline \multirow[t]{2}{*}{ Characteristic } & \multicolumn{2}{|c|}{ sHLA-G (mean \pm SD); ng/ml } & \multirow[t]{2}{*}{$p(\mathrm{pc})$} \\
\hline & UC $(N=30)$ & $\mathrm{CD}(N=30)$ & \\
\hline \multicolumn{4}{|c|}{ Adalimumab or infliximab doses } \\
\hline 0 & $189.7 \pm 26.3$ & $159.8 \pm 10.3$ & 0.079 (NS) \\
\hline $1-10$ & $185.6 \pm 23.7$ & $172.8 \pm 28.1$ & 0.229 (NS) \\
\hline $11-20$ & $176.6 \pm 24.6$ & $161.2 \pm 26.8$ & $0.193(\mathrm{NS})$ \\
\hline $21-30$ & $156.5 \pm 47.5$ & $197.8 \pm 11.5$ & 0.217 (NS) \\
\hline$p(\mathrm{pc})$ & 0.334 (NS) & 0.144 (NS) & \\
\hline
\end{tabular}

Significant $p$ is bold-marked

$S D$ standard deviation, UC ulcerative colitis, CD Crohn's disease, protocol $A$ anti-inflammatory and immunosuppressive, protocol $B$ anti-inflammatory and antibiotics, protocol $C$ anti-inflammatory, immunosuppressive, and antibiotics, protocol $D$ immunosuppressive only, $p$ LSD (least significant) or one-way ANOVA (analysis of variance) probability, $p c$ Bonferroni-corrected probability, NS not significant $(p c>0.05)$

the supernatant of $\mathrm{CD}$ patients showed spontaneous production of sHLA-G [18]. Further accomplishing data suggested that immunosuppressant therapies are able to normalize the production of sHLA-G in CD, while in UC patients such therapy initiates their release. This effect on sHLA-G release was not influenced by age and gender of patients, as well as, disease activity, localization, or duration [40]. In this study, medication showed no significant effect on sHLA-G level. However, there was a tendency for sHLA-G to have a decreased level in UC patients who received immunosuppressive therapy, and the decrease paralleled the number of therapy doses. In $\mathrm{CD}$ patients, the response to medication was different. Patients treated with protocol $\mathrm{C}$ (anti-inflammatory, antibiotics and immunosuppressive) showed the highest level of sHLA-G among the other medication groups. Further, the increased level of sHLA-G paralleled the number of immunotherapy doses (the level was

Table 4 Allele and genotype frequencies of HLA-G 14-bp insertion/deletion polymorphism in healthy populations from Iraq and other countries

\begin{tabular}{|c|c|c|c|c|c|c|c|c|}
\hline \multirow[t]{2}{*}{ Country } & \multirow[t]{2}{*}{$N$} & \multicolumn{2}{|c|}{ HLA-G 14-bp allele } & \multicolumn{3}{|c|}{ HLA-G 14-bp genotype } & \multirow[t]{2}{*}{ HWE $p$} & \multirow[t]{2}{*}{ Reference } \\
\hline & & Ins & Del & Ins/Ins & Ins/Del & Del/Del & & \\
\hline Iraq & 100 & $82(41.0)$ & $118(59.0)$ & $20(20.0)$ & $42(42.0)$ & $38(38.0)$ & 0.187 & Present study \\
\hline Algeria & 100 & $77(38.5)$ & $123(61.5)$ & $15(15.0)$ & $47(47.0)$ & $38(38.0)$ & 0.940 & [22] \\
\hline Brazil & 120 & $107(44.6)$ & $133(55.4)$ & $26(21.7)$ & $55(45.8)$ & $39(32.5)$ & 0.427 & [23] \\
\hline China & 292 & $193(33.1)$ & $391(66.9)$ & $35(12.0)$ & $123(42.1)$ & $134(45.9)$ & 0.411 & [24] \\
\hline Egypt & 100 & $120(60.0)$ & $80(40.0)$ & $38(38.0)$ & $44(44.0)$ & $18(18.0)$ & 0.401 & [25] \\
\hline Greece & 192 & $176(45.8)$ & $208(54.2)$ & $39(20.3)$ & $98(51.0)$ & $55(28.7)$ & 0.698 & [26] \\
\hline India & 383 & $347(45.3)$ & $419(54.7)$ & $86(22.4)$ & $175(45.7)$ & $122(31.9)$ & 0.127 & [27] \\
\hline Iran & 210 & $180(42.9)$ & $240(57.1)$ & $52(24.8)$ & $76(36.2)$ & $82(39.0)$ & $<0.001$ & [28] \\
\hline Italy & 451 & 351 (38.9) & $551(61.1)$ & 65 (14.4) & $221(49.0)$ & 165 (36.6) & 0.514 & [29] \\
\hline Japan & 777 & $389(25.0)$ & 1165 (75.0) & $58(7.5)$ & $273(35.1)$ & $446(57.4)$ & 0.075 & [30] \\
\hline Korea & 491 & $232(23.6)$ & $750(76.4)$ & $17(3.5)$ & $198(40.3)$ & $276(56.2)$ & 0.009 & [31] \\
\hline Mexico & 214 & 195 (45.6) & $233(54.4)$ & 41 (19.2) & $113(52.8)$ & $60(28.0)$ & 0.346 & [32] \\
\hline Poland & 465 & 385 (41.4) & $545(58.6)$ & 77 (16.5) & $231(49.7)$ & $157(33.8)$ & 0.607 & [33] \\
\hline Saudi Arabia & 119 & $117(49.2)$ & $121(50.8)$ & $27(22.7)$ & $63(52.9)$ & $29(24.4)$ & 0.519 & [34] \\
\hline Spain & 33 & $17(25.8)$ & $49(74.2)$ & $2(6.1)$ & $13(39.4)$ & $18(54.5)$ & 0.863 & [35] \\
\hline Tunisia & 170 & $174(51.2)$ & $166(48.8)$ & $42(24.7)$ & 90 (52.9) & $38(22.4)$ & 0.439 & {$[36]$} \\
\hline Turkey & 191 & $188(49.2)$ & $194(50.8)$ & $48(25.1)$ & $92(48.2)$ & $51(26.7)$ & 0.615 & [37] \\
\hline$p$ & & $<0.001$ & & $<0.001$ & & & & \\
\hline
\end{tabular}

Significant $p$ is bold-marked

Ins insertion, Del deletion, HWE Hardy-Weinberg equilibrium, $p$ Pearson's chi-squared test probability 


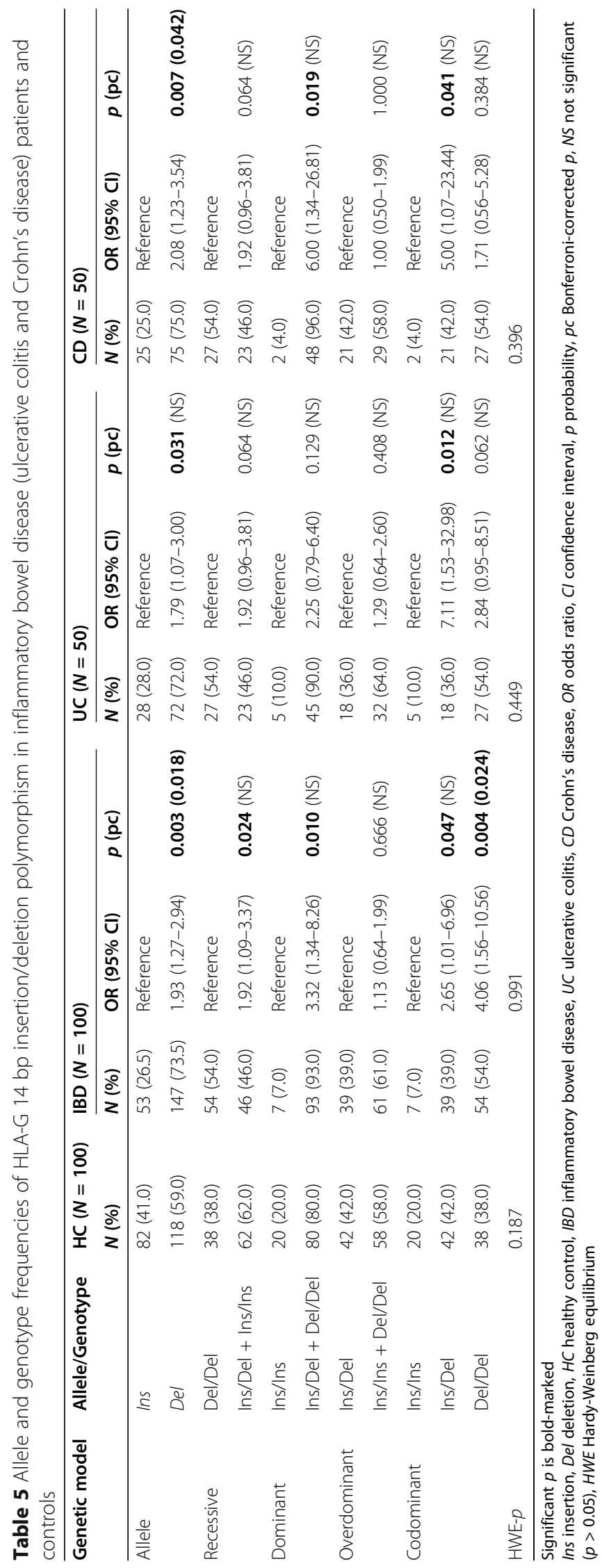


Table 6 Serum level of sHLA-G antigens in inflammatory bowel disease (ulcerative colitis and Crohn's disease) patients and controls distributed according to HLA-G 14-bp insertion/ deletion genotypes

\begin{tabular}{lllll}
\hline Group $^{\mathbf{a}}$ & \multicolumn{2}{l}{ sHLA-G (mean \pm SD); ng/ml } & \multirow{p}{*}{$\boldsymbol{p}$} \\
\cline { 2 - 4 } & Ins/Ins & Ins/Del & Del/Del & \\
\hline Control $(N=19: 5: 6)$ & $122.2 \pm 16.6$ & $135.5 \pm 15.2$ & $126.0 \pm 14.5$ & 0.314 \\
UC $(N=19: 6: 5)$ & $183.7 \pm 17.9$ & $180.0 \pm 46.8$ & $179.8 \pm 22.4$ & 0.958 \\
CD $(N=21: 7: 2)$ & $172.5 \pm 34.9$ & $165.0 \pm 26.2$ & $169.9 \pm 27.0$ & 0.894 \\
\hline
\end{tabular}

UC ulcerative colitis, $C D$ Crohn's disease, SD standard deviation, Ins insertion, Del deletion, $p$ one-way ANOVA (analysis of variance) probability

${ }^{a}$ Numbers of Ins/Ins, Ins/Del, and Del/Del are given in parentheses, respectively

increased in patients who received 21-30 doses). These findings indicted that $\mathrm{UC}$ and $\mathrm{CD}$ patients responded differently to the administrated therapy. Previous in vitro study also suggested that immunosuppressant therapies may act differently in UC and CD patients [40].

Irrespective of these inconsistencies, this study points to the role for sHLA-G molecules in pathogenesis of UC and $\mathrm{CD}$. Both phenotypes presented with upregulated inflammatory responses, and sHLA-G molecules may encounter the exaggerated inflammatory response due to their immunomodulating effects [41]. The HLA-G molecules may protect local tissue by inhibiting the activity of NK cells and may also control the balance between $\mathrm{T}$ helper 1 and 2 cells in mucosa tissues [5].

In the second approach, allele and genotype frequencies of HLA-G 14-bp Ins/Del polymorphism were analyzed in IBD patients (UC and CD) and controls. As in other world populations, both alleles (Ins and $\mathrm{Del}$ ) showed polymorphic frequencies in the Iraqi sample of controls (41 and 59\%, respectively). In most of the populations investigated (Table 4), Ins was the allele of minor frequency and had a range of $23.6 \%$ in Koreans [31] to 49.2\% in Saudi Arabians [34] and Turkish [37]; however, Egyptians [25] and Tunisians [36] showed the opposite profile, and the Ins allele frequency exceeded this range (60 and 51.2\%, respectively). Therefore, the Iraqi Ins allele frequency fits well the presented range. However, the comparison between patients and controls depicted variations in allele and genotype frequencies of HLA-G 14-bp Ins/Del polymorphism. In total IBD patients, as well as CD patients, logistic regression analysis suggested a risk potential of the allele Del. In UC patients, a similar conclusion was reached but the difference was significant before correction of $p$ value. In Caucasian German patients, allele and genotype frequencies of HLA-G 14bp Ins/Del polymorphism showed no significant variations between UC or CD patients and controls, but there were significant differences between $\mathrm{UC}$ and $\mathrm{CD}$ patients. The heterozygous genotype and the Del+ phenotype were significantly elevated in UC patients compared to CD patients [19]. In a Tunisian study, neither allele nor genotype frequencies of HLA-G 14-bp Ins/Del polymorphism showed significant differences between $C D$ patients and controls. However, the distribution of patients as young- and adult-onset showed significantly increased frequencies of Ins allele and Ins/ Ins genotype in young-onset patients but not adult-onset patients [20]. To the best knowledge of investigators, no further study was performed to explore the association of HLA-G 14-bp Ins/Del polymorphism with UC or CD. Although conflicting results were obtained, a possible risk effect of the HLA-G gene in both phenotypes of IBD is suggested.

This study also addressed that the upregulated serum expression of sHLA-G in UC and CD patients might be influenced by HLA-G 14-bp Ins/Del variant. The analysis revealed that sHLA-G level was similarly distributed in the three genotypes of patients or controls, and no significant influence was observed. However, a previous study suggested inconsistent functional relevance, and the exon 8 polymorphism (14-bp Ins/Del) may influence the transcription activity of HLA-G gene [15]. The authors observed that HLA-G mRNAs harboring the 92base deletion showed more stability than complete forms of mRNA. Accordingly, it was suggested that regulation of HLA-G post-transcription is controlled by this region. However, it has been reviewed that presence of Del allele in homozygous and heterozygous genotypes is correlated with higher production of sHLA-G (high-producer genotypes). A similar observation was made in $\mathrm{CD}$ patients, and Del/Del and Del/Ins genotypes were associated with an increased plasma level of sHLA-G, but no statistical significance was attended [20].

\section{Conclusions}

This study demonstrated a significant increase in serum level of sHLA-G in UC and CD patients. Further, HLAG 14-bp Ins/Del polymorphism may be associated with susceptibility to IBD, particularly $\mathrm{CD}$. However, the study was limited by low number of $\mathrm{UC}$ and $\mathrm{CD}$ patients, and increasing the sample size will certainly contribute to a further understanding of HLA-G role in immunopathogenesis of both IBD phenotypes.

\footnotetext{
Abbreviations

ANOVA: Analysis of variance; AUC: Area under curve; bp: Base-pairs: CD: Crohn's disease; Cl: Confidence interval; Del: Deletion; ESR: Erythrocyte sedimentation rate; Hb: Hemoglobin; HLA: Human leukocyte antigen; HWE: Hardy-Weinberg equilibrium; IBD: Inflammatory bowel disease; Ins: Insertion; LSD: Least significant difference; MHC: Major histocompatibility complex; NK: Natural killer; OR: Odds ratio; $p$ : Probability; PBMC: Peripheral blood mononuclear cell; pc: Corrected p; ROC: Receiver operating characteristics; SD: Standard deviation; sHLA-G: Soluble HLA-G; Th: T helper; UC: Ulcerative colitis; WBC: White blood cell
} 


\section{Acknowledgements}

The authors thank the medical staff at Al-Kindy Teaching Hospital, Baghdad Teaching Hospital, and Gastroenterology and Hepatology Teaching Hospital in Baghdad for their cooperation.

\section{Authors' contributions}

SSA handled laboratory assessments, managed data and statistical analyses and contributed to writing and revising the manuscript. ENA and $\mathrm{NHZ}$ contributed to data handling, writing and revising the manuscript. NMA diagnosed the disease, managed data and revised the manuscript. AHA managed data, carried out statistical analyses, and wrote the manuscript. The authors read and approved the final manuscript.

\section{Funding}

This research did not receive any specific grant from funding agencies in the public, commercial, or not-for-profit sectors.

\section{Availability of data and materials}

The datasets used and/or analyzed during the current study are available from the corresponding author on reasonable request.

\section{Ethics approval and consent to participate}

The participants provided their written informed consent to be included in the study. The College of Science (Al-Mustansiriya University) obtained the approval of the Ethics Committees at the target hospitals to carry out the study (N264 on 13 January 2019).

\section{Consent for publication}

Not applicable.

\section{Competing interests}

The authors declare that they have no competing interests.

\section{Author details}

${ }^{1}$ Department of Biology, College of Science, Al-Mustansiriya University, Baghdad, Iraq. ${ }^{2}$ Gastroenterology and Hepatology Teaching Hospital, Baghdad, Iraq. ${ }^{3}$ Tropical-Biological Research Unit, College of Science, University of Baghdad, Al-Jadriya, Baghdad, Iraq.

\section{Received: 4 September 2020 Accepted: 22 October 2020}

Published online: 02 December 2020

\section{References}

1. Eichele DD, Young R (2019) Medical management of inflammatory bowel disease. Surg Clin North Am 99:1223-1235 https:/doi.org/10.1016/j.suc.2019.08.011

2. Ray C, Sagar P (2020) Management of Crohn's disease and ulcerative colitis. Surg (United Kingdom) 38:318-321 https://doi.org/10.1016/j.mpsur.2020.04.003

3. Flynn S, Eisenstein S (2019) Inflammatory bowel disease presentation and diagnosis. Surg Clin North Am 99:1051-1062 https://doi.org/10.1016/j.suc. 2019.08.001

4. Kuhnen A (2019) Genetic and environmental considerations for inflammatory bowel disease. Surg Clin North Am 99:1197-1207 https://doi. org/10.1016/j.suc.2019.08.014

5. Torres MI, Palomeque T, Lorite P (2014) HLA in gastrointestinal inflammatory disorders. In: Xi Y (ed) HLA and Associated Important Diseases. IntechOpen, https://doi.org/10.5772/57497. Available from: https:// www.intechopen.com/books/hla-and-associated-important-diseases/hla-ingastrointestinal-inflammatorydisorders

6. Downs-Kelly E, Schade AE, Hansel DE (2007) The role of HLA-G in gastrointestinal inflammatory disease and malignancy. Semin Cancer Biol 17:451-458 https://doi.org/10.1016/j.semcancer.2007.07.002

7. Gomes RG, de Brito CAA, Martinelli VF, dos Santos RN, dos Santos Gomes F, Peixoto CA et al (2018) HLA-G is expressed in intestinal samples of ulcerative colitis and Crohn's disease patients and HLA-G5 expression is differentially correlated with TNF and IL-10 cytokine expression. Hum Immunol 79:477-484 https://doi.org/10.1016/j.humimm.2018.03.006

8. Alegre E, Rizzo R, Bortolotti D, Fernandez-Landázuri S, Fainardi E, González A (2014) Some basic aspects of HLA-G biology. J Immunol Res 2014 https:// doi.org/10.1155/2014/657625

9. Rebmann V, König L, da Silva Nardi F, Wagner B, Manvailer LFS, Horn PA (2016) The potential of HLA-G-bearing extracellular vesicles as a future element in HLA-G immune biology. Front Immunol 7:1 https://doi.org/10. 3389/fimmu.2016.00173

10. Ferreira LMR, Meissner TB, Tilburgs T, Strominger JL (2017) HLA-G: At the interface of maternal-fetal tolerance. Trends Immunol 38:272-286 https:// doi.org/10.1016/j.it.2017.01.009

11. Rizzo R, Farina I, Bortolotti D, Galuppi E, Rotola A, Melchiorri L et al (2013) HLA-G may predict the disease course in patients with early rheumatoid arthritis. Hum Immunol 74:425-432 https://doi.org/10.1016/j.humimm.2012. 11.024

12. Bertol BC, Dias FC, da Silva DM, Zambelli Ramalho LN, Donadi EA (2019) Human antigen leucocyte (HLA)-G and HLA-E are differentially expressed in pancreatic disorders. Hum Immunol 80:948-954 https://doi.org/10.1016/j. humimm.2019.09.002

13. Contini P, Puppo F, Canonica GW, Murdaca G, Ciprandi G (2016) Allergendriven HLA-G expression and secretion in peripheral blood mononuclear cells from allergic rhinitis patients. Hum Immunol 77:1172-1178 https://doi. org/10.1016/j.humimm.2016.08.005

14. HLA nomenclature 2020. https://hla.alleles.org/nomenclature/index.html. Accessed 20 Apr 2020.

15. Rousseau P, Le Discorde M, Mouillot G, Marcou C, Carosella ED, Moreau P (2003) The 14 bp deletion-insertion polymorphism in the 3' UT region of the HLA-G Gene influences HLA-G mRNA stability. Hum Immunol 64:10051010 https://doi.org/10.1016/j.humimm.2003.08.347

16. Castelli EC, Mendes-Junior CT, Deghaide NHS, De Albuquerque RS, Muniz YCN, Simes RT et al (2010) The genetic structure of 3'untranslated region of the HLA-G gene: polymorphisms and haplotypes. Genes Immun 11:134-141 https://doi.org/10.1038/gene.2009.74

17. Torres MI, Le Discorde M, Lorite P, Ríos A, Gassull MA, Gil A et al (2004) Expression of HLA-G in inflammatory bowel disease provides a potential way to distinguish between ulcerative colitis and Crohn's disease. Int Immunol 16:579-583 https://doi.org/10.1093/intimm/dxh061

18. Rizzo R, Melchiorri L, Simone L, Stignani M, Marzola A, Gullini S et al (2008) Different production of soluble HLA-G antigens by peripheral blood mononuclear cells in ulcerative colitis and Crohn's disease: a noninvasive diagnostic tool? Inflamm Bowel Dis 14:100-105 https://doi.org/10.1002/ibd. 20281

19. Glas J, Töök HP, Tonenchi L, Wetzke M, Beynon V, Teshome MY et al (2007) The 14-bp deletion polymorphism in the HLA-G gene displays significant differences between ulcerative colitis and Crohn's disease and is associated with ileocecal resection in Crohn's disease. Int Immunol 19:621-626 https:// doi.org/10.1093/intimm/dxm027

20. Zidi I, Ben YH, Bortolotti D, Mouelhi L, Laaribi AB, Ayadi S et al (2015) Association between sHLA-G and HLA-G 14-bp deletion/insertion polymorphism in Crohn's disease. Int Immunol 27:289-296 https://doi.org/ 10.1093/intimm/dxv002

21. Veit TD, Cazarolli J, Salzano FM, Schiengold M, Chies JAB (2012) New evidence for balancing selection at the HLA-G locus in South Amerindians. Genet Mol Biol 35:919-923 https://doi.org/10.1590/S141547572012000600005

22. Djidjik R, Gharnaout M, Messaoudani N, Boukouaci W, Benyounes A, Ghaffor $M$ et al (2014) Association of HLA-G 14bp insertion/deletion and TGF- $\beta 1$ polymorphisms with atopic asthma monosensitized against Der $p$ 1: An Algerian study with a review of the literature. Rev Fr Allergol 54:537-543 https://doi.org/10.1016/j.reval.2013.12.005

23. de Albuquerque RS, Mendes-Junior CT, Lucena-Silva N, da Silva CLL, Rassi DM, Veiga-Castelli LC et al (2016) Association of HLA-G 3' untranslated region variants with type 1 diabetes mellitus. Hum Immunol 77:358-364 https://doi.org/10.1016/j.humimm.2016.02.001

24. Zhang X, Li S, Zhang Y, Lu Y, Wang J, Xu J et al (2014) Meta-analysis of the relationship between 14bp insertion/deletion polymorphism of HLA-G gene and susceptibility to systemic lupus erythematosus. Hum Immunol 75:11711176 https://doi.org/10.1016/j.humimm.2014.10.008

25. Tawfeek GAE, Alhassanin S (2018) HLA-G gene polymorphism in Egyptian patients with non-Hodgkin lymphoma and its clinical outcome. Immunol Invest 47:315-325 https://doi.org/10.1080/08820139.2018.1430826

26. Gerasimou P, Skordis N, Picolos M, Spyridonidis A, Costeas P (2016) HLA-G 14-bp polymorphism affects the age of onset in Type I Diabetes Mellitus. Int J Immunogenet 43:135-142 https://doi.org/10.1111/iji.12259

27. Agnihotri V, Gupta A, Kumar R, Upadhyay AD, Dwivedi S, Kumar L et al (2017) Promising link of HLA-G polymorphism, tobacco consumption and risk of Head and Neck Squamous Cell Carcinoma (HNSCC) in North Indian 
population. Hum Immunol 78:172-178 https://doi.org/10.1016/j.humimm. 2016.12.007

28. Mohammadi N, Adib M, Alsahebfosoul F, Kazemi M, Etemadifar M (2016) An investigation into the association between HLA-G 14bp insertion/deletion polymorphism and multiple sclerosis susceptibility. J Neuroimmunol 290: 115-118 https://doi.org/10.1016/j.jneuroim.2015.11.019

29. Rizzo R, Hviid TVF, Govoni M, Padovan M, Rubini M, Melchiorri L et al (2008) HLA-G genotype and HLA-G expression in systemic lupus erythematosus: HLA-G as a putative susceptibility gene in systemic lupus erythematosus. Tissue Antigens 71:520-529 https://doi.org/10.1111/j.1399-0039.2008.01037.x

30. Hachiya Y, Kawasaki A, Oka S, Kondo Y, Ito S, Matsumoto I et al (2016) Association of HLA-G 3' Untranslated region polymorphisms with systemic lupus erythematosus in a Japanese population: A case-control association study. PLoS One 11:1-14 https://doi.org/10.1371/journal.pone.0158065.14

31. Jeong KH, Kim SK, Kang BK, Chung JH, Shin MK, Lee MH (2014) Association between an HLA-G 14 bp insertion/deletion polymorphism and nonsegmental vitiligo in the Korean population. Arch Dermatol Res 306:577582 https://doi.org/10.1007/s00403-014-1459-5

32. García-González IJ, Valle Y, Rivas F, Figuera-Villanueva LE, Muñoz-Valle JF, Flores-Salinas HE et al (2014) The $14 \mathrm{bp}$ Del/Ins HLA-G polymorphism is related with high blood pressure in acute coronary syndrome and type 2 diabetes mellitus. Biomed Res Int 2014 https://doi.org/10.1155/2014/898159

33. Wiśniewski A, Kowal A, Wyrodek E, Nowak I, Majorczyk E, Wagner M et al (2015) Genetic polymorphisms and expression of HLA-G and its receptors, KIR2DL4 and LILRB1, in non-small cell lung cancer. Tissue Antigens 85:466475 https://doi.org/10.1111/tan.12561

34. Hassan MA, Al Omar S, Halawani H, Arafah M, Alqadheeb S, Al-Tamimi J et al (2019) Relationship of HLA-G expression and its 14-bp insertion/deletion polymorphism with susceptibility to colorectal cancer. Genet Mol Res 18:112 https://doi.org/10.4238/gmr18324

35. Torres MI, Luque J, Lorite P, Isla-Tejera B, Palomeque T, Aumente MD et al (2009) 14-Base pair polymorphism of human leukocyte antigen-G as genetic determinant in heart transplantation and cyclosporine therapy monitoring. Hum Immunol 70:830-835 https://doi.org/10.1016/..humimm.2009.07.012

36. Sakly K, Maatouk M, Hammami S, Harzallah O, Sakly W, Feki S et al (2016) HLA-G 14 bp insertion/deletion polymorphism and its association with sHLA-G levels in Behçet's disease Tunisian patients. Hum Immunol 77:90-95 https://doi.org/10.1016/j.humimm.2015.10.016

37. Duman T, Havan M, Özartam S, Tutkak H, Düzgün N (2012) Association of the HLA-G gene 14bp del/ins polymorphism with Behçet's disease. Turkish J Immunol 1:41

38. Parkes GC, Whelan K, Lindsay JO (2014) Smoking in inflammatory bowel disease: Impact on disease course and insights into the aetiology of its effect. J Crohn's Colitis 8:717-725 https:/doi.org/10.1016/j.crohns.2014.02.002

39. Khasawneh M, Spence AD, Addley J, Allen PB (2017) The role of smoking and alcohol behaviour in the management of inflammatory bowel disease. Best Pract Res Clin Gastroenterol 31:553-559 https://doi.org/10.1016/j.bpg. 2017.10.004

40. Zelante A, Borgoni R, Galuppi C, Cifalà V, Melchiorri L, Gullini S et al (2011) Therapy modifies HLA-G secretion differently in Crohn's disease and ulcerative colitis patients. Inflamm Bowel Dis 17:E94-E95 https://doi.org/10 1002/ibd.21756

41. Rizzo R, Bortolotti D, Bolzani S, Fainardi E (2014) HLA-G molecules in autoimmune diseases and infections. Front Immunol 5:592 https://doi.org/ 10.3389/fimmu.2014.00592

\section{Publisher's Note}

Springer Nature remains neutral with regard to jurisdictional claims in published maps and institutional affiliations.

\section{Submit your manuscript to a SpringerOpen ${ }^{\circ}$ journal and benefit from:}

- Convenient online submission

- Rigorous peer review

- Open access: articles freely available online

High visibility within the field

- Retaining the copyright to your article

Submit your next manuscript at $\boldsymbol{\nabla}$ springeropen.com 